\title{
Ca isotope constraints on chemical weathering along the Middle Reaches of Yangtze River, China
}

\author{
YIJUN YANG ${ }^{1,2 *}$, DONALD J. DEPAOLO ${ }^{2}$, \\ YANXIN WANG ${ }^{1}$
}

${ }^{1}$ School of Environmental Studies, China University of Geosciences, Wuhan 430074, China (*correspondence: yijun.yang@cug.edu.cn)

${ }^{2}$ Department of Earth and Planetary Science, University of California, Berkeley, CA 94720, USA

Understanding $\mathrm{Ca}$ isotope variability in groundwaters hosted in different lithologies could provide new insights into processes controlling the $\mathrm{Ca}$ isotope fluxes in the global $\mathrm{Ca}$ budget. Although there are abundant $\mathrm{Ca}$ isotope data from rivers, relatively few groundwater measurements have been reported [1]. We investigated two geographically close but lithologically different aquifer systems along the middle reaches of Yangtze, one of the world's largest rivers. The karst aquifer at Xiangxi River Basin (XRB) drains carbonate rocks and the Quaternary aquifer at Jianghan Plain (JHP) drains mostly silicates. Ca isotopes in groundwater, along with hydrochemistry and $\mathrm{Sr}$ isotopes were measured in 27 samples. The dominant cations and anions are $\mathrm{Ca}, \mathrm{Mg}$, and $\mathrm{HCO}_{3}{ }^{-}$. Most of the waters are oversaturated with respect to calcite and dolomite. Measured $\delta^{44 / 40} \mathrm{Ca}$ values in XRB and JHP vary from -0.44 to $-0.05 \%$ and -0.37 to $+0.06 \%$ (versus BSE), respectively. The silicate aquifer generally has higher $\mathrm{Ca}$ concentrations and slightly heavier $\delta^{44 / 40} \mathrm{Ca}$ values than the carbonate aquifer. Although the $\mathrm{Ca}$ isotope variations are small, there is a significant correlation between $\delta^{44 / 40} \mathrm{Ca}$ and $\mathrm{Mg} / \mathrm{Ca}$. There is also a positive correlation between ${ }^{87} \mathrm{Sr} /{ }^{86} \mathrm{Sr}$ and $\mathrm{Mg} / \mathrm{Sr} \quad(\mathrm{R}=0.72, \mathrm{P}<0.01)$. An endmember carbonate signature appears to be one of relatively low ${ }^{87} \mathrm{Sr} /{ }^{86} \mathrm{Sr}(<$ 0.710 ), low $\delta^{44 / 40} \mathrm{Ca} \approx-0.4 \%$, and low $\mathrm{Mg} / \mathrm{Ca}$ as might be expected. Carbonate hosted groundwaters with higher $\delta^{44 / 40} \mathrm{Ca}$ also have higher $\mathrm{Mg} / \mathrm{Ca}$, suggesting that calcite precipitation has affected the $\mathrm{Ca}$ isotope signatures. Silicate hosted groundwaters have slightly higher $\delta^{44 / 40} \mathrm{Ca}$ mostly between -0.20 and $+0.06 \%$, similar to likely average values for the continental crust, and ${ }^{87} \mathrm{Sr} /{ }^{86} \mathrm{Sr}$ between 0.7103 and 0.7118 are also close to the estimated average global riverine flux. Thus, our results suggest that although there are slight differences in source $\mathrm{Ca}$ isotope ratios for silicate and carbonate aquifers, calcite precipitation tends to narrow the differences so that average groundwater $\delta^{44 / 40} \mathrm{Ca}$ values are close to BSE values.

[1] Fantle et al. (2014) Earth-Sci. Rev. 129, 148-177. 